\title{
PUBLIC PROCUREMENT, STATE ASSETS AND INCLUSIVE TOURISM: SOUTH AFRICAN DEBATES
}

\author{
Christian M. ROGERSON* \\ University of Johannesburg, School of Tourism and Hospitality, College of Business \\ and Economics, Bunting Road, Johannesburg, South Africa, e-mail: crogerson@uj.ac.za \\ Jayne M. ROGERSON \\ University of Johannesburg, School of Tourism and Hospitality, College of Business \\ and Economics, Bunting Road, Johannesburg, South Africa, e-mail: jayner@uj.ac.za
}

\begin{abstract}
Citation: Rogerson C.M. \& Rogerson J. M. (2019). PUBLIC PROCUREMENT, STATE ASSETS AND INCLUSIVE TOURISM: SOUTH AFRICAN DEBATES. GeoJournal of Tourism and Geosites, 26(3), 686-700. https://doi.org/10.30892/gtg.26301-389
\end{abstract}

\begin{abstract}
Inclusive tourism represents a concept which is attracting major interest in international literature and an increasing policy focus in South Africa. Public procurement is used in South Africa as a vehicle for supporting national development goals. Against the background of growing interest on the behalf of South Africa's national government to utilize public procurement for leveraging a more inclusive development path the aim is to direct attention to the potential application of public procurement as a vehicle for enhanced inclusion in the country's tourism sector. Three sections of discussion are presented. As essential context the first section reviews international debates around public procurement as a policy tool. The second section turns attention to ongoing South African debates and policy initiatives around the leveraging of public procurement. State assets are the focus in the third section and their use through public procurement as a potential policy vehicle for inclusive tourism development in South Africa. In terms of methodology the paper draws upon a critical analysis of international experience of procurement, a review and analysis of policy documents, and published and unpublished data on immovable state assets that can be applied potentially in using public procurement for inclusive tourism development in South Africa. The central argument is multiple opportunities exist for public procurement to lever state assets in support of the goals of inclusive tourism development in South Africa.
\end{abstract}

Key words: Inclusive tourism, public procurement, tourism policy, South Africa

\section{INTRODUCTION}

The concept of inclusive tourism currently is a major research focus in international tourism scholarship (Bakker \& Messerli, 2017; Indriani et al., 2017; Biddulph, 2018; Campos et al., 2018; Scheyvens \& Biddulph, 2018). It is a concept that is

\footnotetext{
* Corresponding author
} 
also attracting mounting interest in South Africa (Butler \& Rogerson, 2016; Bukula, 2018; Rogerson \& Rogerson, 2019). At a major conference of tourism stakeholders during August 2015 the Minister of Tourism Derek Hanekom proclaimed that among key objectives of South Africa's future tourism policy in future was that "we want to make the entire sector more inclusive and representative by bringing people who have been marginalized into the mainstream tourism economy" (Hanekom, 2015: 2).

The theme of developing a more inclusive tourism sector has been re-iterated subsequently in several other government statements and documents. Most importantly, the achievement of "inclusive and quality growth of the South African tourism economy" is viewed as a foundation of the country's National Tourism Sector Strategy (Department of Tourism, 2018: 18). In this regard, of particular note was that in May 2017 the Minister of Tourism announced that state-owned assets and properties would be leveraged to support tourism SMMEs for inclusive tourism (Ensor, 2017). In addition, as part of its initiatives for inclusive tourism the Department of Tourism itself would 'walk the talk' through using the Department's own procurement budget in a deliberate move to support and promote black entrepreneurs. The term 'public procurement' "refers to the purchase of goods and services by government or public entities to fulfil their various functions" (Bolton, 2016: 4). The critical relevance of public procurement as a policy tool for achieving the goals of national government is underlined by commitments made in the National Development Plan (NDP) 2030 (The Presidency, 2011).

The NDP asserts that public procurement "will be an essential stimulator of demand for small and expanding firms" (The Presidency, 2011: 119). A recent World Bank (2018) diagnostic report on the South African economy identifies the application of public procurement as one of the policy tools currently applied to address what it calls the 'incomplete transition' following democratic change. It is against the backdrop of growing interest on the behalf of South Africa's national government to utilize public procurement for leveraging a more inclusive development path, including for the tourism sector, that the objective in this paper is to direct attention to the potential application of public procurement as a specific vehicle for enhanced inclusion in the country's tourism sector.

In terms of methodology the paper draws upon a critical analysis of international experience of procurement, a review and analysis of policy documents, and published and unpublished data on immovable state assets that can be applied potentially in using public procurement for inclusive tourism development in South Africa. Three sections of discussion are presented. As context the first section reviews international debates around public procurement as a policy tool. The second section turns attention to ongoing South African debates and policy initiatives around the leveraging of public procurement. The third section turns attention to state assets and directs attention to public procurement as a potential policy vehicle for inclusive tourism development in South Africa.

\section{LEVERAGING STATE PROCUREMENT: THE INTERNATIONAL EXPERIENCE}

As argued by Hoekman \& Sanfilippo (2018: 1) governments around the world purchase a large variety of products from the private sector and such state procurement often accounts for "a significant share of GDP and thus aggregate demand". According to the UNEP (2017: viii) public procurement wields enormous power, accounting for an average of $12 \%$ GDP in the group of OECD countries and reaching as much as $30 \%$ in many developing countries. In countries of the global South Wittig (1999: 3) identifies the public procurement sector as "often the largest domestic market". Likewise, Hoekman \& Sanfilippo (2018) confirm that in some of the poorest regions of the world, including subSaharan Africa, the magnitude of public procurement is highly significant in configuring 
the economic landscape. Conventionally state procurement systems incorporate procedures to ensure that contracts are awarded to the lowest cost suppliers that satisfy particular technical specifications. This said, in most countries value for money is not the only goal of public procurement as many governments also have leveraged state procurement in order to pursue other social or distributional objectives (Nijaki \& Worrel, 2012; Flynn \& Davis, 2015; UNEP, 2017; Loader, 2018).

The use of public procurement to drive innovation is a strong focus particularly in the European Union where "the purchasing power of governments is being recognised as a demand-side tool that can stimulate innovation" (Bolton, 2016: 4). Most recently, the application of public procurement has been extended to achieve environmental objectives with much attention devoted to issues of 'green procurement' or sustainable procurement in which SMMEs are a major priority for target support (Nijaki \& Worrel, 2012; UNEP, 2017; Delmonico et al., 2018). Low carbon procurement is also a new research agenda particularly in Europe - as a response to the importance of addressing climate change issues (Correia et al., 2013). Overall, across the international scholarship among key barriers identified to successful procurement are that "often people do not see public procurement as strategic or even a real profession", "competing procurement priorities", "lack of awareness" and in the developing world "lack of products or services to procure" (UNEP, 2017). In emerging economies questions around sustainable public procurement have attracted academic attention with work suggesting that "organizational culture stands out as a particular barrier" (Delmonico et al., 2018: 70).

Across the region of sub-Saharan Africa there is a growing literature on issues around public procurement (African Procurement Law Unit, 2018). Most existing African literature focuses on issues of governance, legal issues, reduction of corruption, the development of enhanced institutional and management frameworks and firm performance (eg. Quinot \& Arrowsmith, 2013; Williams-Elegbe, 2013; Leon de Mariz et al., 2014; Uromi, 2014; Williams-Elegbe, 2015; Ambaw \& Telgan, 2017; Engelbert et al., 2016; Engelbert, 2017; African Procurement Law Unit, 2018; Hoekman \& Sanfilippo, 2018). Beyond these studies, one must note Akenroye et al. (2013) on the implementation of green public procurement in Nigeria, Mphela \& Shunda (2018) on the challenges for SMMEs to engage with public procurement in Botswana, Israel \& Gazungu (2019) on procurement and SMMEs in Tanzania, and, Amoah \& Shakantu (2017) on public procurement preferences in Ghana in support of the local construction industry. African research which examines issues of public procurement and social inclusion include works by Bolton (2006, 2008a) on South Africa and most recently by Basheka (2018) on Uganda.

Notwithstanding policy interest in many advanced and emerging economies for leveraging public procurement it is observed that public procurement remains a relatively neglected theme for academic research (Thai, 2001; Mahmood, 2010). Most especially attention has lagged in respect of how it can be utilised to promote entrepreneurship (Preuss, 2011). Nevertheless, as discussed below, public sector procurement has been applied as a lever for SMME development in several countries to catalyse market access for certain preferred groups of SMMEs, an initiative which emerges out of a longer history of leveraging state procurement. Historically, it is argued that the application of "public procurement as a tool to advance national priorities can be traced back to the $19^{\text {th }}$ century when procurement was used to tackle social justice issues such as fair labour conditions and wages or improved opportunities for disabled people"(UNEP, 2017: 10). McCrudden (2004) provides a valuable overview of how governments attempt to use procurement to produce desired social outcomes regulating the use of its purchasing power to advance conceptions of social justice. Indeed, it is suggested that at least in the global North "modern procurement systems evolved alongside the development of the welfare State, 
and it is hardly surprising that the former was used in part to underpin the goals of the latter" (McCrudden, 2004: 258). For example, in the United Kingdom after World War 1 public procurement was applied to address the needs of disabled ex-servicemen with the establishment of sheltered workshops where limited types of goods were made and given preference in government purchasing. In the USA similar initiatives were introduced during the 1930 s to support the blind. Such early initiatives to leverage the power of public procurement extended in scope and in geographical context (McCrudden, 2004).

In the international scholarship around public procurement much interest centres on the United States experience of affirmative action programmes in which conditions were attached to government contractors for non-discrimination practices. Provisions were enacted to ensure through 'set-asides' such that a determined proportion of government contracts be secured by black owned businesses "in an attempt to further the development of an entrepreneurial black middle class" (McCrudden, 2004: 260). Indeed, the most striking application of set asides has been to nurture the development of "minority businesses" (mainly African-American owned enterprises) in the USA; later the focus of these programmes expanded to include other minority groups (especially Hispanics) as well as women-owned businesses (Sonfield 2010). By the 1960s these programmes were extended "to ensure that businesses owned by women would also secure a proportion of government contracts” (McCrudden, 2004: 261).

The core legislative thrust was designed "to promote equality and social cohesion through a policy of 'affirmative action' by having 'set asides' for socially and economically disadvantaged owners of small businesses" (Centre for Research in Ethnic Minority Entrepreneurship, 2007: 9). For Preuss (2011: 790) the focus of these programmes "is to counteract social exclusion through support for women- and minority-owned enterprises". Arguably whilst the USA enjoys a long history of set aside programmes which can be traced back even as far as the 1930s (House-Soremekun, 2007: 20), the most important developments occurred in the 1960s and 1970s. In the USA the 'small business set aside' is widely used to support market access for small business. It restricts or sets aside certain contracts exclusively for small business participation. Under the Small Business Set-Aside Program US small businesses are assisted to win government contracts. More explicitly, the programme assures small businesses are awarded a 'fair proportion' of government contracts through reserving certain purchases exclusively for small business suppliers (House-Soremekun, 2007).

The leveraging principle of public procurement to support disadvantaged groups in the USA has been extended and replicated in several other countries. In the United Kingdom during the 1960s legislation was introduced to support ethnic minority businesses (mainly by Asian immigrants) through public procurement (Ram \& Smallbone, 2003). Loader (2018) identifies a continuing emphasis in the UK experience of applying public procurement policy to assist SMEs especially in the period 2010-2015. Also, in Canada set-asides are used in certain government contracts with mandatory provisions for Aboriginal suppliers through an Aboriginal business procurement policy (Orser 2009). Instead of relying on procurement goals or targets which relate to small business sourcing, often from disadvantaged groups in Canada "set-asides reserve certain purchases for competition only among a certain group of disadvantaged owners of SMEs" (Orser, 2009: iii). In the case of Malaysia public procurement was strategically applied to assist the develop of native Malays (Bumiputeras) through according a margin of price preference over a reference price for government contracts (McCrudden, 2004).

A 2006 law in Brazil grants set asides to small businesses and gives priority to small businesses on purchases under a cost limit of 80 ooo reals (Timm, 2015).In India procurement rules stipulate that certain products are 'set aside' and must be purchased 
exclusively from the small-scale sector in order to support artisans and small-scale firms even if prices charged are up to $15 \%$ higher than those offered by competitors (McCrudden, 2004). During 2015 India enacted a policy that obliges state-owned enterprises and departments of central governments to source $20 \%$ of goods and services from small enterprises (Timm, 2015). The following section turns to the South African record and broad debates about leveraging public procurement.

\section{LEVERAGING PUBLIC PROCUREMENT IN SOUTH AFRICA}

According to McCrudden (2004) in its changed policies relating to procurement post-1994 South Africa borrowed extensively from the policy experience of both Canada and Malaysia. Bolton (2006: 193) makes clear that prior to the democratic transition in 1994 the government procurement system in South Africa favoured large and established businesses and created an environment in which it was very difficult for small enterprises to enter the procurement system. In 1994, however, government procurement was granted constitutional status and acknowledged as a vehicle for addressing past discriminatory practices (Bolton, 2008a, 2008 b). Public procurement has been applied since 1994 as a policy tool "to correct South Africa's history" (Bolton, 2006: 202) and "address past apartheid injustices" (Bolton, 2016: 10). Of critical importance has been that in procuring goods and services, organs of the South African government are required to take into account a number of factors when awarding state contracts.

As Bolton (2006: 202) stresses the concept of "empowerment" "plays an important role in determining whether or not a contract is awarded to a particular contractor". Provision is made for the implementation of a policy of what is described as "affirmative" or "targeted" procurement which is aimed "at providing employment and business opportunities for marginalized individuals and communities - referred to as 'target groups" (Bolton, 2008a: 2). Since 2000 much progress has been made to establish a supportive policy and legislative environment for preferential procurement with the implementation of a number of policies beginning with the 2000 Preferential Procurement Policy Framework Act (PPFA) (Rogerson, 2004). South Africa is observed as one "of few countries in the world to have procurement subject to its Constitution" (Herrington \& Overmeyer, 2006: 9). According to Bolton (2016) the key legislation provisions of the PPPFA and Regulations provide a national framework for the roll out and implementation of preferential procurement policies in South Africa.

In addition to the policy focus on Black Economic Empowerment, growing interest centred on using public procurement as a strategic tool to support the objectives of policies for the development of small, medium and micro-enterprises (SMMEs) (Osiba Research, 2011). Arguably, SMME development promotion through public procurement can contribute also to achieving the goals of pro-poor local economic development in South Africa (Rogerson, 2014). One recent report asserted that "South Africa could vamp up support to small businesses if it looked at setting aside certain types of procurement for SMEs, as a number of countries like South Korea, the US and Japan already do" (Timm, 2011: 43). This said, the possible use of public procurement to support SMME development has been under discussion for several years in South Africa. In 1994 a report was submitted on the contribution of "emerging enterprises" to both public and private sector procurement programmes. This report was authored jointly by the World Bank and a South African reference group on small business development convened by the Ministry of Trade and Industry (The Reference Group on Small Business Development and the World Bank, 1994). Thus as far back as 1995, procurement reform began and focused on good governance in procurement and the attainment of socio-economic objectives through procurement, including SMME development (Rogerson, 2004). During 1995 
national government adopted a Ten Point Plan to furnish SMMEs with opportunities to participate in government procurement thereby offering them a range of new markets for their goods and services. This particular initiative was followed up in 1997 by the production of a handbook of procurement guidelines for SMMEs and service providers relating to markets in the state sector (Ntsika, 1997).

The appearance of these various reports following democratic transition demonstrates that the basic issues around creating market opportunities for SMMEs through public procurement are not new in South African policy debates (Rogerson, 2004a). In 2005 following the presentation of the Integrated Small Enterprise Development Strategy, the official framework for small business development policy in South Africa, Cabinet proposed that government implement a procurement programme that gave effect to the procurement of specified 10 products from all government departments and state agencies (Department of Trade and Industry, 2006).

Cabinet proposed that the Department of Trade and Industry (DTI) jointly with National Treasury identify the ten products to be recommended as suitable for this programme and further prepare recommendations on procurement, reporting and monitoring measures designed to ensure that proper guidelines are in place for implementation of this programme as a government wide strategy to expand market access to SMMEs utilizing government procurement opportunities (DTI, no date). A DTINational Treasury Task Team completed an analysis of government procurement trends using a sample of departments and government procurement related research material. The outcome was the identification of ten products for government procurement from small enterprises which was presented in a Cabinet memorandum which was approved by Cabinet in November 2007. Under the approved "Ten Products Initiative" government would only procure certain products from (black) SMMEs. The Government Preferential Procurement for Small Enterprise Products and Services isolated ten product and service categories to be supplied by SMMEs (Kaiser Associates, 2010).

The ten identified product categories considered as targets for SMMEs were advertising, media and communication; interior and exterior cleaning services and cleaning product supplies; clothing and textiles; computer equipment and consumable supplies; interior and exterior furniture and décor; events coordination and management; maintenance and repairs, construction, office space, furniture and vehicle body works; travel coordination and shuttle services; food perishable supplies (catering); and, stationary supplies and printing (Kaiser Associates, 2010). Implementation of this initiative, however, was stalled such that whilst government was encouraging (and increasingly compelling) the private sector through B-BBEE codes to expand linkages with black-owned enterprises it has not been practicing this in its own direct procurement. As is made clear by Mesatywa (2011) the strength of National Treasury in inter-departmental decision-making around procurement policy is extremely powerful. The practice is that "organs of the state follow National Treasury prescripts" with the consequence that the B-BBEE Act has largely been unused in state procurement (Mesatywa, 2011: 9). Current support directions were linked therefore to the implementation of the Preferential Procurement Act which gives "preference" in tenders to black suppliers. Other initiatives surrounded establishment of a National Procurement Portal. The intention of this initiative is to address poor access to markets by creating a platform which will host all procurement/tender opportunities of government departments (Breytenbach, 2011). In addition, it would do the following.

First, is to improve information accessibility on opportunities to suppliers, and information to buyers so as to increase the participation of small enterprises in public sector tendering and in requests for quotation. Second, is to streamline procurement 
processes in order to reduce administrative burden for SMMEs. Three, is support for collaboration between the public and private sector on information on opportunities. Four, is to enhance adherence to timings/deadlines on contract advertisement, award, delivery and payment cycles. Last, is to strengthen information access and transparency of government procurement processes (Breytenbach, 2011).

Overall, however, it is pointed out that whilst the national government in South Africa is the champion of B-BBEE policy as well as SMME development and the largest procurer of goods and services in the country, examination of its own procurement spend and procedures suggests that it is often not supporting its own policies by its practices (Herrington \& Overmeyer, 2006: 25). Critically, it is revealed that government spending not only has been insufficient on preferential procurement but also and most especially so in respect of its contribution to (black) small enterprise development. Further criticism are directed at national government for raising expectations that market access for SMMEs through government's own initiatives would be improved but then failing to implement promised policies and procedures that already were announced.

One recent detailed report on public procurement in South Africa contains several critical policy findings relating to SMMEs (Kaiser Associates, 2010). In particular, concern was expressed that the current direction of "preferential procurement legislation is shifting toward BBBEE enterprises, and away from SMMEs" (Kaiser Associates, 2010: 9). As a whole, this shift was reflected in the emphasis given to B-BBEE points in the procurement regulations which were gazetted in June 2011 which sought to align the B-BBEE policy with the Public Procurement Policy Framework Act (Mesatywa, 2011). From the perspective of National Treasury, the outcome of these regulations was that public procurement in South Africa must be directed by preferences to be given to SMMEs rather than through use of set-asides.

A new chapter opened in 2011 with the publication of the revised Preferential Procurement Regulations. According to the National Treasury (2017) this was influenced by the need to provide a mechanism to empower through procurement certain defined categories of SMMEs also classified as Exempt Micro Enterprises (EMEs) or Qualifying Small Enterprises (QSEs), Cooperatives, Townships and Rural Enterprises ${ }^{1}$. The backdrop was that this was an outcome of social dialogue on the New Growth Path wherein government and social partners signed a Local Procurement Accord on 31 October 2011 which solidified a government commitment to leverage public procurement. The 2011 revised regulations were aligned also to the pronouncements made in the 2015 State of the Nation Address made by President Zuma (National Treasury, 2017). Specifically, it was announced that government would 'set-aside' $30 \%$ of state procurement for certain defined categories of state enterprises (Timm, 2015; Bolton, 2016). As a consequence, the National Treasury began an engagement process with the Department of Small Business Development to craft a 'practice note' governing set asides and thus reverse its previous block on DTI initiatives which sought to ensure that the state buy $85 \%$ of the 10 designated categories of goods and services from small businesses (Timm, 2015).

In February 2015 the National Treasury published a procurement review document which signaled its potential greater acceptance of the use of set asides. It stated that measures to promote preference and socio-economic transformation "would be conditional on these being able to keep cost premiums to a minimum and being aligned to Section 217 (1) of the constitution" which reads state procurement is conditional on a

\footnotetext{
${ }^{1}$ In terms of BBBEE legislation EMEs are the smallest entities with an annual turnover of R1o million or less. QSEs are those with an annual turnover of between R10 million and R50 million. Beyond these two categories are Generic Enterprises or GENs which are the largest enterprises with an annual turnover exceeding R50 million.
} 
system that is "fair, equitable, transparent, competitive and cost-effective" (Timm, 2015). The World Bank (2018: 69) cautions that for South Africa the absence of sunset clauses in the set aside legislation means that "firms may never achieve competitive levels outside of government procurement" and thus might "remain dependent on government at the expense of the taxpayer". It was reported that substantial pressure was brought by the lobbying undertaken by the Black Business Council for National Treasury to drop its opposition to set-asides and further amend the regulations in the Preferential Procurement Policy (Ntingi, 2016). On 20 January 2017 the National Treasury gazetted the revised Preferential Procurement Regulations making these the second round of revisions since their initial promulgation in 2001 (National Treasury, 2017).

According to the World Bank (2018: 71) the revised public procurement regulations which will establish the Office of the Chief Procurement Officer "to provide for an agile system of preference that will support socioeconomic transformation". The revised regulations include the provision that organs of the state be required "to identify tenders, where it is feasible, to sub-contract a minimum of $30 \%$ of the value of the contract for contracts above R30 million” for supporting SMME development (National Treasury, 2017). More specifically, the legislation is directly targeted to those categories of SMMEs as defined in terms of the Broad-Based Black Economic Empowerment as either EMEs or QSEs (National Treasury, 2017). The specific details as set out below are that a tenderer must subcontract a minimum of $30 \%$ of the value of the contract to:

(a) an EME or QSE;

(b) an EME or QSE which is at least $51 \%$ owned by black people;

(c) an EME or QSE which is at least $51 \%$ owned by black people who are youth;

(d) an EME or QSE which is at least $51 \%$ owned by black people who are women;

(e) an EME or QSE which is at least 51\% owned by black people with disabilities;

(f) an EME or QSE which is at least $51 \%$ owned by black people living in rural or underdeveloped areas or townships;

(g) a cooperative which is at least $51 \%$ owned by black people;

(h) an EME or QSE which is at least $51 \%$ owned by black people who are military veterans; or

(i) more than one of the categories referred to in paragraphs (a) to (h) (National Treasury, 2017).

In the framework agreement of the 2018 Presidential Jobs Summit the leveraging of public procurement was isolated as critical for SMME development. It was stated that whilst "some progress has been made in leveraging Government procurement for SMME growth, much more still needs to be done to achieve the maximum impact of this policy" (Republic of South Africa, 2018: 46).

Key areas for policy attention include increasing awareness campaigns targeted at procurement officials to ensure implementation of the policy and strengthening the reporting and monitoring of information in order to enable the improved and effective tracking of the 30 percent set aside (Republic of South Africa, 2018). During 2018 the National Treasury recorded the abuse in certain provinces and municipalities of the requirement that 30 percent of public procurement contracts be subcontracted to designated groups in terms of the 2017 Preferential Procurement Regulations.

It was alleged "that some people are now demanding that they, instead, be paid in cash $30 \%$ of the value of each contract awarded in these provinces and municipalities" and failing that payment "they threaten contractors, interrupt or stop the implementation of projects" (National Treasury, 2018: 1). In addition, the National Treasury draws attention also to certain practices in terms of procurement preferences that are not provided for in terms of the existing regulatory framework. 
Of note in particular, is that existing regulations seemingly do not permit geographical area preferences. The National Treasury (2018: 1) states that irregular practices include "the ring fencing of procurement for service providers and suppliers who live within certain geographical areas". It is made clear that government funds "spent on tenders awarded in this manner will be classed as irregular expenditure since they do not comply with the Supply Chain Management and Preferential Procurement Provisions and prescripts" (National Treasury, 2018: 1). The 2017 Preferential Procurement Regulations were introduced as a temporary measure and will be superseded by the new Public Procurement Bill which was due to be ready in late 2018. From the perspective of the World Bank (2018: 91) the existing procurement policy framework exhibits "very complex overlapping objectives" which "are often competing, and they remain difficult to implement and measure". The forthcoming Bill is set to repeal the Preferential Procurement Policy Framework Act in its entirety. For the National Treasury (2018) the Bill will consolidate various laws which currently deal with procurement and enable government to more effectively use public procurement as a strategic lever for inclusive growth objectives (Ensor, 2018). According to the Department of Small Business Development (2018: 15) once it is enacted this "will be the single national regulatory framework for public procurement" in South Africa. Potentially, according to national Treasury, the bill "will give provinces the flexibility to determine their own transformation and empowerment strategies and programmes based on their local economic development needs within the broader national framework" (Ensor, 2018: 1).

\section{NEW PUBLIC PROCUREMENT AND TOURISM IN SOUTH AFRICA}

The new public procurement measures in South Africa were informed by the ongoing policy narrative concerning inclusive growth. According to the responsible Minister the measures were applied "to use public procurement as a lever to promote socio-economic transformation, empowerment of small enterprises, rural and township enterprises, designated groups and promotion of local industrial development" (National Treasury, 2017). Although no explicit mention was given to tourism the regulations open up the possibility of extending the leveraging of public procurement into South Africa's tourism economy. This said, as is demonstrated in the above discussion there exists an extensive body of international evidence for using public procurement for the support of national development goals and including of objectives surrounding SMME development. Indeed, it was shown through the international record that public procurement can be a useful tool to be applied to achieving a range of different development goals. Nevertheless, within extant international literature Hjalager (2002) points out there has been almost no discussion of the application of public procurement to support specifically tourism businesses. Arguably, this assessment which was made about the tourism sector in the early 2000 s remains valid nearly two decades later.

In South Africa, however, there is an awakening of policy interest to the extended application of public procurement as a means for achieving a greater inclusive tourism sector to address existing lack of inclusivity (Rogerson \& Rogerson, 2019). This interest builds upon the national government's commitment to expand the involvement of black entrepreneurs in the country's SMME economy and especially the country's growing tourism sector (Rogerson, 2005). For more than a decade there has been an existing commitment in South Africa in terms of national government's policies relating to the management of immovable assets that public assets be used optimally to support attainment of government objectives including poverty alleviation, job creation and black economic empowerment (Department of Public Works, 2005, 2008). Implementation of this policy, however, has been slowed by the absence of a comprehensive register of such 
state assets. The country's Department of Small Business Development is leading a national initiative to integrate the small business support activities of several government departments in South Africa including of the Department of Tourism (Department of Small Business Development, 2018). It stresses that one of the key interventions for promoting SMMEs is through the strengthening of government public procurement programmes for leveraging improved market access for local SMMEs. As one of the participants in the National Interdepartmental Committee which is responsible for these interventions, the Department of Tourism has an important role especially in light of the significance of SMMEs in South Africa's tourism economy as well as potential for further development (Rogerson, 2005). During 2017 South Africa's Department of Tourism signalled that policy consideration was being given to leverage the opportunities of stateowned assets for tourism development and in particular for SMME upgrading by black entrepreneurs (Ensor, 2017). An initial step towards achieving this objective is the pursuit by the Department of Tourism of a national audit of such state tourism-related assets. Arguably, the extent of government assets that can be leveraged through public procurement regulations is considerable. The state apparatus in South Africa consists of three tiers of government - national, provincial and local. At each respective tier there exist a suite of important assets that can be leveraged for a more inclusive tourism development.

Table 1. State Assets for Leveraging Tourism Development: SANParks (Source: Authors. Note: Gemsbok National Park and Richtersveld National Park are now incorporated as part of two Transfrontier National Parks)

\begin{tabular}{|l|c|c|c|}
\hline \multicolumn{1}{|c|}{ Name } & Province & Established & Size (sqkm) \\
\hline Addo Elephant Park & Eastern Cape & 1931 & 1642 \\
\hline Agulhas National Park & Western Cape & 1998 & 56.9 \\
\hline Augrabies Falls National Park & Northern Cape & 1966 & 417 \\
\hline Bontebok National Park & Western Cape & 1931 & 27.9 \\
\hline Camdeboo National Park & Eastern Cape & 2005; 1979 as Karoo Nature Reserve & 194 \\
\hline Garden Route National Park & Western Cape & $\begin{array}{c}\text { 2009; 1964 as Tstitsikamma National } \\
\text { Park; 1985 as Wilderness National } \\
\text { Park, Knysna National Lake Area }\end{array}$ & 1570 \\
\hline Gemsbok National Park & & 1931 & 9591 \\
\hline Golden Gate National Park & Northern Cape & 1963 & 116 \\
\hline Karoo National Park & Free State & 1979 & 831 \\
\hline Kruger National Park & Western Cape & 1926 & 19623 \\
\hline Mapungubwe National Park & Limpopo & 1995 & 53.6 \\
\hline Marakele National Park & Limpopo & 1994 & 507 \\
\hline Mokala National Park & Northern Cape & 2007 & 196 \\
\hline Mountain Zebra National Park & Eastern Cape & 1937 & 284 \\
\hline Namaqua National Park & Northern Cape & 1999 & 1350 \\
\hline Richtersveld National Park & Northern Cape & 1991 & 1624 \\
\hline Table Mountain National Park & Western Cape & 1998 & $\mathbf{2 4 3}$ \\
\hline Tankwa Karoo National Park & Northern Cape & 1986 & 1216 \\
\hline West Coast National Park & Western Cape & 1985 & 363 \\
\hline
\end{tabular}

At the national and provincial scale of government the 'jewels in the crown' of state assets are the network of game reserves - many of them 'big 5' wildlife attractions - as well as an array of smaller protected areas which are important for biodiversity conservation. At the apex of the management of significant state assets for tourism development is South African National Parks (SANParks) an organization formed in 1926 with responsibility for managing 22 different parks (19 functional) consisting of over 4 million hectares or roughly 3 percent of the total area of South Africa. The list of national parks shows their different areal extent, varying dates of establishment and size variations. Among the rich assets under the administration of SANParks are some of South Africa's most iconic attractions for both international as well as domestic tourists, 
namely Kruger Park, Table Mountain National Park, Garden Route National Park and Addo Elephant Park. SANParks assumes a major role in promoting nature-based tourism or ecotourism businesses across the country. Beyond the wilderness protected areas under the management of SANParks there are other significant nature tourism assets which fall under the responsibility of provincial authorities in South Africa. For the province of KwaZulu-Natal the Ezemvelo KZN Wildlife (formerly Natal Parks Board) is responsible for maintaining wildlife and conservation at several major parks including most notably at the UNESCO World Heritage Sites of iSimangaliso Wetland Park and the Natal Drakensberg Park, the latter part of the Maloti-Drakensberg Transfrontier Conservation Area (Van der Merwe, 2019). CapeNature (officially the Western Cape Nature Conservation Board) manages 25 wilderness areas and public nature reserves across Western Cape Province. In North West province a key institutional actor is North West Parks Board. This organisation includes amongst its assets the Pilanesberg Game Reserve which is an expanding tourism node because of its accessibility only $50 \mathrm{kms}$ from the Sun City gambling and leisure mega-resort and two hour drive from Johannesburg or Pretoria. Other provincial organisations which manage assets for nature-based tourism or ecotourism include Eastern Cape Parks, the Mpumalanga Tourism and Parks Agency and the Gauteng Department of Agriculture and Rural Development.

Table 2. State Assets by Category: Western Cape

(Source: Unpublished Department of Tourism Database)

\begin{tabular}{|c|c|}
\hline Type of Asset & Number \\
\hline Nature reserve & 28 \\
\hline Holiday resorts & 22 \\
\hline Camping or Caravan Park & 15 \\
\hline Museum & 7 \\
\hline Heritage site & 7 \\
\hline Botanical or Nature Garden & 6 \\
\hline Harbours & 5 \\
\hline Beach & 5 \\
\hline Visitor Centre & 5 \\
\hline Historic view site & 1 \\
\hline Research Conservation Centre & 1 \\
\hline Cultural Centre & 1 \\
\hline Community farm & 1 \\
\hline Hiking trail & 1 \\
\hline Lighthouse & 1 \\
\hline
\end{tabular}

Notes; (1) Data base reflects reporting municipalities only, (2) Category of holiday resorts also includes several which offer camping and caravan sites, (3) Several nature reserves offer various forms of accommodation

All these national or provincial agencies are subject to compliance with national and/or (aligned) provincial government procurement regulations and therefore have assets that can be, to varying degrees, leveraged for supporting the involvement of black SMMEs either in tourism activities directly or as suppliers in supply chains to these organisations and their related activities including, in some instances, also for the provision of a range of accommodation services. Finally, at the municipal or local level of government there is a further suite of state assets that potentially can be leveraged for assisting SMME development linked to tourism through using public procurement levers. The wide range of these municipal assets can be appreciated by examining the unpublished data base on municipal tourism assets which has been prepared by South Africa's Department of Tourism. Although this data base is admittedly incomplete and 
offers only partial coverage it does allow a glimpse and indication of the types of assets under municipal control. The broad range and character of municipal tourism assets that might be leveraged through public procurement for tourism SMME development can be gleaned from an analysis of municipal assets which are recorded for two provinces in this data set. The choice of Western Cape (Table 2) and Eastern Cape (Table 3) provinces is influenced simply by the quality of responses received from its various municipalities about the existence of their local assets.

Table 3. State Assets by Category: Eastern Cape (Source: Unpublished Department of Tourism Database)

\begin{tabular}{|l|c|}
\hline \multicolumn{1}{|c|}{ Type of Asset } & Number \\
\hline Nature reserve & 35 \\
\hline Heritage site & 16 \\
\hline Camping or Caravan Park & 14 \\
\hline Conference facility & 10 \\
\hline Dams & 9 \\
\hline Beach & 7 \\
\hline Museum & 6 \\
\hline Visitor Centre & 6 \\
\hline Arts Centre & 6 \\
\hline River & 6 \\
\hline Botanical Garden & 4 \\
\hline Stadium & 4 \\
\hline Holiday Resorts & 3 \\
\hline Hiking trail & $\mathbf{2}$ \\
\hline Water Falls & $\mathbf{2}$ \\
\hline Cultural Village & $\mathbf{1}$ \\
\hline Aquarium & $\mathbf{1}$ \\
\hline Zoo & $\mathbf{1}$ \\
\hline Harbour & $\mathbf{1}$ \\
\hline Bowling & $\mathbf{1}$ \\
\hline
\end{tabular}

Notes; (1) Data base reflects reporting municipalities only, (2) Category of holiday resorts also includes several which offer camping and caravan sites. (3) Several nature reserves offer various forms of accommodation

Several points can be observed from an examination of Tables 2 and 3 . The range of assets is broad as is indicated also from other provinces which list also a range of conference centres, dams, zoo, aquarium, sports stadia, picnic sites. Arguably, however, across the reporting provinces and on the basis of the existing limited data, the most common forms of municipal assets that might be leveraged for tourism relate to nature reserves, holiday resorts, camping and caravan parks, museums and heritage sites, botanical or nature gardens, harbours and beaches. Potentially there exist geographical variations in terms of inter-provincial differences in the kinds of state assets that might be leveraged. Of particular note in Eastern Cape is the significant number of conference centres that are listed; in Western Cape this category of assets was not mentioned at all.

In addition to these major state assets there are a large number of smaller municipal assets which include local nature reserves, accommodation complexes, camp sites, heritage sites, caravan parks and even a number of lighthouses that might be leveraged through public procurement for greater inclusive growth in South Africa. Arguably, potential opportunities exist through leveraging these and similar assets by using public procurement to support the goals of tourism development in South Africa. The implementation of public procurement can be utilized to expand initiatives for supporting black-owned SMMEs in tourism or incorporating black SMMEs as suppliers in tourism value chains associated with state assets. 
This conclusion about extending the reach of targeted pubic procurement into the tourism sector of South Africa points to the critical importance of undertaking research to monitor the leveraging of state assets for supporting South Africa's nationally proclaimed objective of a more inclusive tourism economy.

\section{Acknowledgement}

Thanks are due to South Africa's Department of Tourism for financial support of the research reported in this paper as well as making available or access to certain unpublished documents and data to assist this research. Comments from reviewers also were most appreciated.

\section{REFERENCES}

Akenroye, T.O., Oyegoke, A.S. \& Eyo, A.B. (2013). Development of a Framework for the Implementation of Green Public Procurement in Nigeria. International Journal of Procurement Management, 6 (1).

Ambaw, B.A. \& Telgan, J. (2017). The Practice of Performance-based Contracting in Developing Countries' Public Procurement: The Case of Ethiopia. Journal of Public Procurement, 17 (3), 402-431.

Amoah, C. \& Shakantu, P.W. (2017). The Effectiveness of the Preference Policies in the Ghanaian Procurement Law in Promoting the Local Construction Industry. Journal of Construction Project Management and Innovation, 7 (1), 1859-1876.

Bakker, M. \& Messerli, H. (2017). Inclusive Growth versus Pro-Poor Growth: Implications for Tourism Development. Tourism and Hospitality Research, 17 (4), 384-391.

Basheka, B.C. (2018). Inclusive Public Procurement: Opportunities, Barriers and Strategies (OBS) to Women Entrepreneurs Participation in Public Procurement in Uganda. Administratio Publica, 26 (1), 86-106.

Biddulph, R. (2018). Social Enterprise and Inclusive Tourism: Five Cases in Siem Reap, Cambodia. Tourism Geographies, 20 (4), 610-629.

Bolton, P. (2006). Government Procurement as a Policy Tool in South Africa. Journal of Public Procurement, 6(3), 193-217.

Bolton, P. (2008a). Protecting the Environment through Public Procurement: The Case of South Africa. Natural Resources Forum, 32(1), 1-8.

Bolton, P. (2008b). The Public Procurement System in South Africa: Main Characteristics. Public Contract Law Journal, 37 (4), 781-802.

Bolton, P. (2016). Public Procurement as a Tool to Drive Innovation in South Africa. Potchefstroom Electronic Law Journal 2016 (19).

Breytenbach, T. (2011). Integrated Small Enterprises Supplier Development Programme. Pretoria: Small Enterprise Development Agency.

Bukula, S. M. (2018). What SMEs Can Do To Increase Their Inclusion in the Tourism Value Chain. In Sustainable Tourism Partnership (comp.), The Responsible and Sustainable Tourism Handbook: South Africa Volume 6, Cape Town: Alive2green, 88-91.

Butler, G. \& Rogerson, C.M. (2016). Inclusive Local Tourism Development in South Africa: Evidence from Dullstroom. Local Economy, 31 (1-2), 264-281.

Campos, M.J.Z., Hall, C.M. \& Backlund, S. (2018). Can MNCs Promote More Inclusive Tourism?: Apollo Tour Operator's Sustainability Work. Tourism Geographies, 20 (4), 630-652.

Correia, F., Howard, M., Hawkins, B., Pye, A. \& Lamming, R. (2013). Low Carbon Procurement: An Emerging Agenda. Journal of Purchasing and Supply Management, 19 (1), 58-64.

Delmonico, D., Jabbour, C.J.C., Pereira, S.C.F., de Sousa Jabbour, A.B.L., Renwick, D.W.S. \& Thome, A.M.T. (2018). Unveiling Barriers to Sustainable Public Procurement in Emerging Economies: Evidence From a Leading Sustainable Supply Chain Initiative in Latin America. Resources, Conservation and Recycling, 134, 70-79.

Dilger, R.J. (2010) Small Business Administration HUBZone Program. Washington DC: Congressional Research Service Report.

Engelbert, A. (2017). Public Procurement Law in Sub-Saharan Africa: A Means to Curb Corruption?. BadenBaden: Nomos.

Engelbert, A., Kaltenborn, M. \& Reit-Born, N. (2016). Effective Corruption Control - Supplier Remedies in Public Procurement in Kenya, Uganda and Tanzania - A Comparative Analysis of Mechanisms and Their Implementation. Berlin: Logos Verlag. 
Ensor, L. (2017). New Fund Will Encourage Inclusive Growth in Tourism Sector, Tokozile Xasa Says. Available at Https:///www.businesslive.co.za/bd/economy/2017-05-08 [Accessed 2 May 2018].

Ensor, L. (2018). Transformation Framework: Treasury Plans to Redo Procurement Laws. Available at https://www.businesslive.co.za/bd/national/2018-04-24 [Accessed 25 June, 2018].

Flynn, A. \& Davis, P. (2015). The Rhetoric and Reality of SME-friendly Procurement. Public Money and Management, 35 (2), 111-118.

Hanekom, D. (2015). Keynote Address Delivered by Minister of Tourism, Derek Hanekom, at the SATSA Conference at Fancourt, George 14 August. Available at www.tourism.gov.za/AboutNDT/Ministry /News/Pages/Hanekom_SATSA-Conference [Accessed 8 September 2015].

Herrington, M.D. \& Overmeyer, T. (2006). Study on the Procurement Relationship between Large Corporations and Mainly Black Owned or Empowered SMEs. Report prepared for ECI Africa, Johannesburg.

Hjalager, A.M. (2002). Repairing Innovation Deficiencies in Tourism. Tourism Management, 23 (5), 465-474.

Hoekman, B. \& Sanfilippo, M. (2018). Firm Performance and Participation in Public Procurement: Evidence from Sub-Saharan Africa. Florence: European University Institute, Working Papers RSCAS 2018/16.

House-Soremekun, B. (2007). The Impact of Minority Set-aside Programs on Black Business Success in Cleveland, Ohio: Implications for Public Policy. Western New England Law Review 30(19), 19-37.

Indriani, Y., Dasuki, R.E. \& Wipartini, Y. (2017). Inclusive Economic Development Model as The Alternative of Sustainable Social-economy Engineering: A Case of Tourism-based Social Economy Development in Wakatobi Regency. European Journal of Economics and Business Studies, 3 (2), 124-130.

Israel, B. \& Kazungu, I. (2019). The Role of Public Procurement in Enhancing Growth of Small and Medium Sized-Enterprises: Experience from Mbeya, Tanzania. Journal of Business Management and Economic Research, 3 (1), 17-27.

Leon de Mariz, C., Menard, C. \& Abeiille, B. (2014). Public Procurement Reforms in Africa: Challenges in Institutions and Governance. Oxford: Oxford University Press

Loader, K. (2018). Small-and Medium-sized Enterprises and Public Procurement: A Review of the UK Coalition Government's Policies and Their Impact. Environment and Planning C: Politics and Space, 36 (1), 47-66.

Mahmood, S. A. I. (2010). Public Procurement and Corruption in Bangladesh: Confronting the Challenges and Opportunities. Journal of Public Administration and Policy Research, 2(6), 103-111.

McCrudden, C. (2004). Using Public Procurement to Achieve Social Outcomes. Natural Resources Forum, 28, 257-267.

Mesatywa, N. (2011). Levering public procurement. Paper Presented at the Annual Small Business Summit, 12 October, Bloemfontein, South Africa.

Mphela, T. \& Shunda, J.P. W. (2018). Can Small, Medium and Micro Enterprises Survive in Public Procurement? Lessons from Botswana. Journal of Public Procurement, 18 (2), 90-110.

Nijaki, L.K. \& Worrel, G. (2012). Procurement for Sustainable Local Economic Development. International Journal of Public Sector Procurement, 25 (2), 133-153.

Ntingi, A. (2016). Tender Set-asides Part of New BEE narrative. Available at https://www.fin24.com/ Finweek/Opinion/tender-set-asides-part-of-new-bee-narrative [Accessed 17 May 2018].

Ntsika (1997). Markets in the State Sector: Procurement Guidelines for Small, Medium and Micro Enterprises (SMMEs) and Service Providers. Pretoria: Ntsika and DTI.

Orser, B. (2009). Procurement Strategies to Support Women-owned Enterprises. Ottawa: Canada Works Limited.

Osiba Research (2011). Rethinking Small Business Support in South Africa. Pretoria: Department of Trade and Industry, Pretoria.

Preuss, L. (2011). On the Contribution of Public Procurement to Entrepreneurship and Small Business Policy. Entrepreneurship and Regional Development, 23 (9-10), 787-814.

Quinot, G. \& Arrowsmith, A. eds. (2013). Public Procurement Regulation in Africa. Cambridge: Cambridge University Press.

Ram, M. \& Smallbone, D. (2003). Policies to Support Ethnic Minority Enterprise: The English Experience. Entrepreneurship and Regional Development, 15(2), 151-166.

Rogerson, C.M. (2004). Pro-poor Local Economic Development in South Africa: The Application of Public Procurement. Urban Forum, 15, 180-210.

Rogerson, C.M. (2005). Unpacking Tourism SMMEs in South Africa: Structure, Support Needs and Policy Response. Development Southern Africa, 22 (5), 623-642.

Rogerson, C.M. (2014). Reframing Place-based Economic Development in South Africa: The Example of Local Economic Development. Bulletin of Geography: Socio-Economic Series, 24, 203-218

Rogerson, C.M. \& Rogerson, J.M. (2019). Tourism, Local Economic Development and Inclusion: Evidence from Overstrand Local Municipality, South Africa. GeoJournal of Tourism and Geosites, 25 (2), 293-308.

Scheyvens, R. \& Biddulph, R. (2018). Inclusive Tourism Development. Tourism Geographies, 20 (4), 589-609.

Sonfield, M. (2010). Ethnic Minority Businesses and Targeted Assistance Programs in the U.S. and the UK: A Comparison and Implications. Small Business Institute National Proceedings, 34 (Winter), 11-17. 
Thai, K.V. (2001). Public Procurement Re-examined. Journal of Public Procurement, 1(1), 9-50.

Timm, S. (2011). How South Africa Can Boost Support to Small Businesses: Lessons from Brazil and India. Pretoria: Trade and Industrial Policy Secretariat.

Timm, S. (2015). 30\% Set-aside For Small Biz. Available at http://www.smallbusinessconnect.co.za/news/30set-aside-for-small-biz.html [Accessed 17 May 2018].

Uromi, S.M. (2014). Challenges Facing Public Procurement Information in some African Countries Namely South Africa, Uganda, Zimbabwe and Tanzania. International Journal for Innovation Education and Research, 2 (7), 54-60.

Van der Merwe, C. (2019). The Geography of Heritage in South Africa. In: J. Knight \& C.M. Rogerson (eds.), The Geography of South Africa: Contemporary Changes and New Directions, Cham: Springer International, 133-141.

Williams-Elegbe, S. (2013). The World Bank Influence on Procurement Reform in Africa. African Journal of International and Comparative Law, 21 (1), 95-119.

Williams-Elegbe, S. (2015). A Comparative Analysis of the Nigerian Public Procurement Act Against International Best Practice. Journal of African Law, 59 (1), 85-98.

Wittig, W.A. (1999). Building Value Through Public Procurement: A Focus on Africa. Paper Presented at the $9^{\text {th }}$ International Anti-Corruption Conference, 10-15 October, Durban.

*** African Procurement Law Unit (2018). Public Procurement Regulation in Africa: Bibliography 2018. Stellenbosch: University of Stellenbosch African Procurement Law Unit.

*** Centre for Research in Ethnic Minority Entrepreneurship (2007). Supplier Diversity: A Guide for Purchasing Organisations. Leicester: De Montfort University.

**** Department of Public Works (2005). Government-Wide Immovable Asset Management Policy. Pretoria: Department of Public Works.

*** Department of Public Works (2008). Immovable Asset Management in National and Provincial Government: Guideline for Custodians. Pretoria: Department of Public Works.

*** Department of Small Business Development (2018). Functions Aligned to the Mandate of DSBD. Pretoria: DBSD.

**** Department of Tourism (2018). National Tourism Sector Strategy 2016-2026. Pretoria: Department of Tourism.

*** Department of Trade and Industry (2006). Integrated Small-Enterprise Development Strategy: Unlocking the Potential of South African Entrepreneurs. Pretoria: Department of Trade and Industry.

*** Department of Trade and Industry (no date) [2009?]. Targeted Procurement for Small Enterprises. Unpublished Brief prepared for NEDLAC, Johannesburg.

*** Kaiser Associates (2010). Public Sector Procurement from Small, Medium and Micro Enterprises (SMMEs). Cape Town: Kaiser Associates.

*** National Treasury (2017). Media Statement: Revised Preferential Procurement Regulations, 2017. Pretoria: National Treasury.

*** National Treasury (2018). Media Statement: Alleged Abuse of the 30\% Subcontracting Requirements Provided for in the Preferential Procurement Regulations, 2017. Pretoria: National Treasury.

*** Republic of South Africa (2018). Presidential Jobs Summit Framework Agreement. 4 October.

*** The Presidency (2011). National Development Plan: Vision for 2030. Pretoria: National Planning Commission.

*** The Reference Group on Small Business Development and the World Bank (1994). Public and Private Sector Procurement Programmes and Their Contribution to Emerging Enterprises in South Africa. Paper presented at the Workshop on Small, Medium and Micro Enterprise Development and Financing, Pretoria, 3 November.

*** UNEP (United Nations Environment Programme) (2017). Global Review of Sustainable Public Procurement. Nairobi: UNEP.

*** World Bank (2018). An Incomplete Transition: Overcoming the Legacy of Exclusion in South Africa. Washington DC: The World Bank Report No. 125838-ZA.

Submitted:

24.03.2019
Revised:

15.07.2019
Accepted and published online 01.08.2019 